\title{
Response of a Scots pine (Pinus sylvestris) stand to applica- tion of phosphorus, potassium, magnesium and lime. 2. Soil solution composition
}

\author{
G. ÁRNOLD, I.L. SWEERS \& A. VAN DIEST \\ Department of Soil Science and Plant Nutrition, Wageningen Agricultural University, \\ $P, O, B o x 8005$, NL 6700 EC Wageningen, Netherlands
}

Received 7 May 1993; accepted 5 Jüly 1993

\begin{abstract}
In a previous paper the effects of liming and $\mathrm{P}, \mathrm{K}$ and $\mathrm{Mg}$ fertilization on the extractable and total nutrient concentrations in the forest floor and mineral soil of a Scots pine stand were discussed. The present paper regards the influence of $\mathrm{P}, \mathrm{K}$ and $\mathrm{Mg}$ addition (as one treatment) and liming on solute concentrations at depths of $30 \mathrm{~cm}$, i.e. in the root zone (monitored September 1989 - April 1992) and 100-150 cm, i.e. below the root zone (April 1991). The latter are compared with previous results. Liming increased $\mathrm{NO}_{3}$ concentrations at both depths, At $30 \mathrm{~cm}$ this effect of liming gradually vanished during the monitoring period, concurrently with a declining soil solution $\mathrm{pH}$, while an increasing effect of $\mathrm{PKMg}$ on $\mathrm{NO}_{3}$ developed, Probably it took several years for the nitrifying microflora to adapt to an improved nutrient availability, while the effect of liming was instantaneous. These data show that besides liming, fertilization may increase $\mathrm{NO}_{3}$ leaching. $\mathrm{NH}_{4}$ was not affected by any treatment. The applied $\mathrm{K}$ and $\mathrm{Mg}$ compounds were easily soluble, and their soil solution concentrations were increased at both depths in the PKMg-amended plots. Probably slow-release fertilizers would allow for a more efficient incorporation of $\mathrm{K}$ and $\mathrm{Mg}$ into the system's biomass. Reducing effects of liming on soluble Al were weak $(30 \mathrm{~cm})$ or absent $(100-150 \mathrm{~cm})$. $\mathrm{Al}$ at $30 \mathrm{~cm}$ did not reach concentrations known to be harmful to $\mathrm{Scots}$ pine, but $\mathrm{Ca}: \mathrm{Al}$ ratios were critical in the unlimed plots. No evidence is found for an enhanced cation leaching caused by an increased formation of nitric acid in the limed plots.
\end{abstract}

Keywords: forest fertilization, leaching, liming, Pinus sylvestris, root zone, soil solution chemistry

\section{Introduction}

The soil solution is the carrier for transport in the soil system (Bolt and Bruggenwert, 1978). Therefore, the dissolved nutrient pool has a major effect on the uptake rate of plant roots (Mengel and Kirkby, 1987; Nye and Tinker, 1977) but also on nutrient leaching (Matzner et al., 1983; Vitousek et al., 1979). Necessarily, to have any effect on plants, fertilization and liming treatments should influence nutrient concentrations in the soil solution, but preferably not to such an extent that 


\section{G. ARNOLD, I.L. SWEERS AND A. VAN DIEST}

leaching is enhanced. The balance between increased uptake and leaching depends on the added amounts and the timing of the application. In agriculture, to optimize nutrient uptake and minimize leaching, split applications have become common practice, and the potential to adjust fertilizer additions more closely to crop demand is still increasing. Fertilization and liming in forestry are applied far less frequently, because they are more laborious than in agriculture (Leek, 1990) and the trees can profit from one application for many years. Inevitably, if fertilization is aimed at an increased nutrient availability for more than one season, nutrients are likely to leach in regions with a precipitation excess, especially during the dormant season, thus making it difficult to manipulate the balance between uptake and leaching. A possible tool to minimize leaching is the use of slow-release fertilizers, which will improve the incorporation of nutrients in the ecosystem biomass (Anon., 1990) and minimize losses during the vegetative period.

Liming is rarely aimed at increasing $\mathrm{Ca}$ availability but mostly at improving chemical and structural soil conditions. However, it may affect the concentrations of many elements in the soil solution by raising the $\mathrm{pH}$, which affects chemical equilibria and microbial activity, and by exchange processes. Since the added amounts are usually very large compared to fertilization, liming may have a profound influence on the uptake and leaching of nutrients other than $\mathrm{Ca}$.

In a Scots pine forest a fertilization experiment was carried out (Arnold \& van Diest, 1993a), in which the effects of fertilizer and lime applications on the soil solution composition were investigated. Soil moisture in and below the root zone was analyzed to assess the effects on nutrient availability and on possible leaching, respectively.

\section{Materials and methods}

The experimental area is situated near Harderwijk, the Netherlands. The soil is a coarse sandy fluvioglacial deposit covered by a fine drift sand layer of varying depth $(10-40 \mathrm{~cm})$ with a weak podzolic soil formation and a litter layer that is distinct from the underlying mineral soil. The water table is at ca. $9 \mathrm{~m}$. The site was planted with Scots pine (Pinus sylvestris L.) in 1960.

Initial soil data are presented in Table $1 . \mathrm{P}, \mathrm{K}, \mathrm{Mg}$ and lime were applied to $22 \times$ $25-\mathrm{m}$ plots in a $2^{4}$ factorial complete randomized block design with 3 replicates. These treatments are denoted as $\mathrm{P}, \mathrm{K}, \mathrm{Mg}$ and $\mathrm{Ca}$, respectively (Table 2). For more details, see Arnold \& van Diest (1993a).

\section{Sampling}

Root zone. Starting in September 1989, soil moisture sampling was carried out in the Control-, Ca- and PKMg plots. Since 22 February 1991, also the PKCaMg plots were sampled, resulting in a $2^{2}$ experiment derived from the $2^{4}$ experiment. For sampling, per plot 4 ceramic high-flow tension cups (Soil Moisture Equipment Corporation) were installed 6 months in advance at a $30-\mathrm{cm}$ depth, i.e. in the rooting zone. The cups had first been rinsed with dilute $\mathrm{HCl}$ and demi water. At a $30-\mathrm{cm}$ 
Table I. Initial element concentrations in the forest floor, and in the $\mathbf{0 - 2 5}$ and $25-50 \mathrm{~cm}$ mineral soil segments,

\begin{tabular}{|c|c|c|c|c|}
\hline \multirow[t]{2}{*}{ Blement } & \multirow{2}{*}{. } & \multicolumn{3}{|l|}{ Soil layer } \\
\hline & & $\begin{array}{l}\text { forest floor } \\
\left(\mathrm{g} \mathrm{kg}^{-1}\right)\end{array}$ & $\begin{array}{l}0-25 \mathrm{~cm}^{-1} \\
\left(\mathrm{mg} \mathrm{kg}^{-1}\right)\end{array}$ & $\begin{array}{l}25-50 \mathrm{~cm} \\
\left(\mathrm{mg} \mathrm{kg}^{-1}\right)\end{array}$ \\
\hline DON $^{2}$ & & - & 4.6 & 2.3 \\
\hline $\mathrm{NO}_{3}$ & 2 & - & 0.0 & 0.0 \\
\hline $\mathrm{NH}_{4}$ & & - & 4.0 & 1.1 \\
\hline $\mathrm{K}^{\prime \prime}$ & &.- & 5.8 & 2.1 \\
\hline $\mathrm{Mg}$ & & - & 1.7 & 0.6 \\
\hline $\mathrm{pH}$ & & & 4.24 & 4.56 \\
\hline$N$ total & 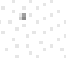 & 15.7 & 454 & 263 \\
\hline P total & + & 0.62 & 102 & 142 \\
\hline $\mathrm{K}$ tolal & & 0.80 & 632 & 728 \\
\hline Ca total & & 1.20 & 69 & 74 \\
\hline Mg total & & 0.33 & 29 & 38 \\
\hline $\mathrm{Zn}$ total & & - & 8 & 10 \\
\hline
\end{tabular}

"Dissolyed organic nitrogen.

depth, sand of variable texture and low in organic matter is found. For installation a hole was drilled with a gouge at a $45^{\circ}$ angle, just above the required depth. The place for the cup was prepared by forcing a PVC tube into the bottom end of the hole, so that the centre of the cup would be $30 \mathrm{~cm}$ below the mineral soil surface. A ceramic cup was firmly pressed into this slightly undersized cavity. Next, the soil material was packed back into the hole, restoring the original stratification. The cup was connected with a spaghetti-tube that was plugged into a bottle, which was brought to a suction pressure of $\mathrm{ca} .15 \mathrm{KPa}(0.15 \mathrm{bar})$. The bottles were buried under the litter layer to avoid light exposure and warming, and they were changed every 2 or 3 weeks.

Leaching. In order to assess the influence of liming and fertilization on the leaching

Table 2. Amounts and compositions of fertilizers and lime applied in the factorial experiment and at the $3000 \mathrm{~kg}$ lime level of the liming experiment.

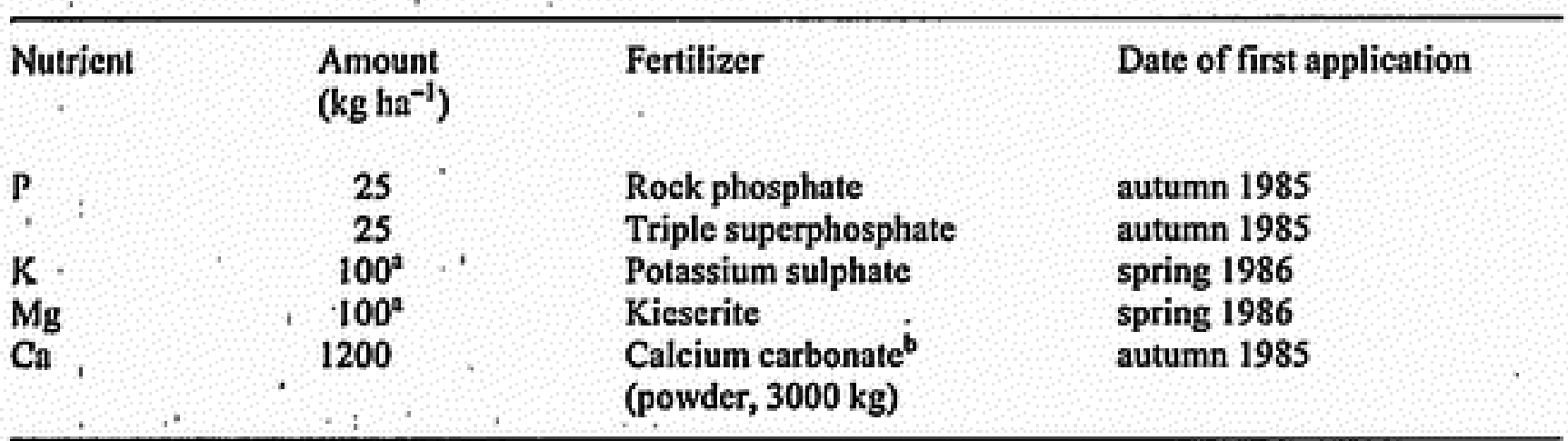

" $\mathrm{K}$ and $\mathrm{Mg}$ applications were split, with additional applications made in the springs of 1987 and 1988, to $n$ total of $100 \mathrm{~kg} \mathrm{ha}^{-1}$ each. ${ }^{b}$ Contained $3.6 \% \mathrm{MgCO}_{3}(1 \% \mathrm{Mg})$. 
of several elements, in April and May 1991 the soil solution of the $100-150 \mathrm{~cm}$ layer mineral soil in the above-mentioned $2^{2}$ experiment was sampled. In April, little annual differences in soil water storage are found, making this the best sampling time for comparing different years (Van Grinsven, 1988). In a neighbouring pine stand, De Visser (1991) found that the fine root biomass and fine root density had reached very low values below a $60 \mathrm{~cm}$ depth. Hence, elements at a $100-150 \mathrm{~cm}$ depth are unlikely to be recovered by root uptake. Nine points per plot were sampled in a regular grid, First, a hole was drilled with an auger to a $100 \mathrm{~cm}$ depth. Into this hole a PVC tube was inserted to prevent collapse and contamination by surface-soil material. Next, the 100-150 cm layer was sampled with a smaller auger. In April, 2 experimental blocks were sampled and 1 block at the beginning of May. The soil samples were kept frozen in plastic bags until further handling. The soil solution was collected by centrifugation at 7000 r.p.m. for 15 min using a method similar to that described by Reynolds (1984), and stored frozen until analysis.

\section{Analyses and statistics}

Analysis of $\mathrm{N}$ species and $\mathrm{K}$ were measured in an automated continuous-flow system as described previously (Arnold \& van Diest, 1993a). In all subsoil solution samples and in some $30 \mathrm{~cm}$ samples (depending on available labour and the amount of solution left after routine analysis) $\mathrm{Al}, \mathrm{Ca}$ and $\mathrm{Mg}$ were measured with an ICP. Occasionally, $\mathrm{Mg}$ in the $30 \mathrm{~cm}$ soil solution was measured by flame AES. $\mathrm{Cl}^{-}$was measured with a coulometer. $\mathrm{Cl}^{-}$is relatively inert with respect to surface exchange (especially if $\mathrm{SO}_{4}{ }^{2-}$ is present) and chemical reactions, and is rather constant in precipitation. Therefore, its concentration fluctuates with, and thus reflects the soil's

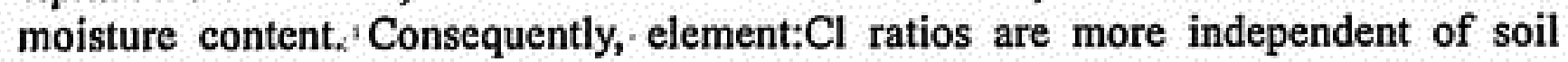
moisture content than element concentrations, and these ratios can therefore be used as an index of the amounts of nutrients present in the soil zone extracted by the cup (c.f. Tietema and Verstraten, 1992). However, such estimates are rather rough and were therefore used only for comparisons between treatments.

For statistical analysis SAS software (SAS Institute Inc., 1990) was used. The data were not normally distributed, for which reason medians rather than means were calculated per sampling date and per plot for both sampling depths. The medians were analyzed with the SAS GIm procedure for a correct handling of missing data. A probability level of $5 \%$ was denoted as significant. For the $30 \mathrm{~cm}$ soil solution data obtained before January 1991, means were separated using the Ryan-Einot-GabrielWagner F test as supplied in the SAS GIm procedure. This test is fully compatible with the overall Anova F test (c.f. SAS manual: GLM Procedure). Hence, it will only indicate pairwise significant differences at $P$ values $\leq P$ from the overall $\mathrm{F}$ test, in contrast with some other multiple comparison tests, like Duncan's multiple range test. For data obtained later, the $2^{2}$ design allowed a more efficient statistical analysis and more often treatment effects appeared to be significant. Still, on many individual sampling dates no significant treatment effects occurred. However, time-plots may show (insignificant) differences that persist for a certain period of time, which qualitatively proves that the treatments did have an influence in that period. 


\section{Results and discussion}

\section{Soll solution composition at $30 \mathrm{~cm}$ depth}

$\mathrm{pH}$, The $\mathrm{pH}$ was variable throughout the season, but did not show any general trend in time, except for the Ca treatment, where a gradual decrease was observed in 1989 and 1990 (Fig. 1). Before January 1991, only for two dates significantly higher $\mathrm{pH}$ values for the lime treatment were found; afterwards it frequently occurred that $\mathrm{Ca}$ raised, and $\mathrm{PKMg}$ reduced the $\mathrm{pH}$ significantly. In summer, the $\mathrm{pH}$ at the $\mathrm{PKMg}$ treatment frequently made a sharp drop. However, these values were based on only one or a few observations, always including those from one sampling cup that extracted relatively large amounts of soil water. The solution $\mathrm{pH}$ values were in the same range as the $\mathrm{pH}-\mathrm{CaCl}_{2}$ values (Arnold \& van Diest, 1993a).

$\mathrm{NO}_{3}$. Generally, the $\mathrm{NO}_{3}$ concentrations and amounts showed an increasing trend during the sampling period. Only for the $\mathrm{Ca}$ treatment a decreasing trend was seen since the end of 1990 (Fig. 2). Each year, peak concentrations occurred in the autumn and winter. This indicates that ammonification and nitrification proceed when plant uptake is reduced during the dormant season, which is likely to cause $\mathrm{N}$ leach-

$\mathrm{pH}$

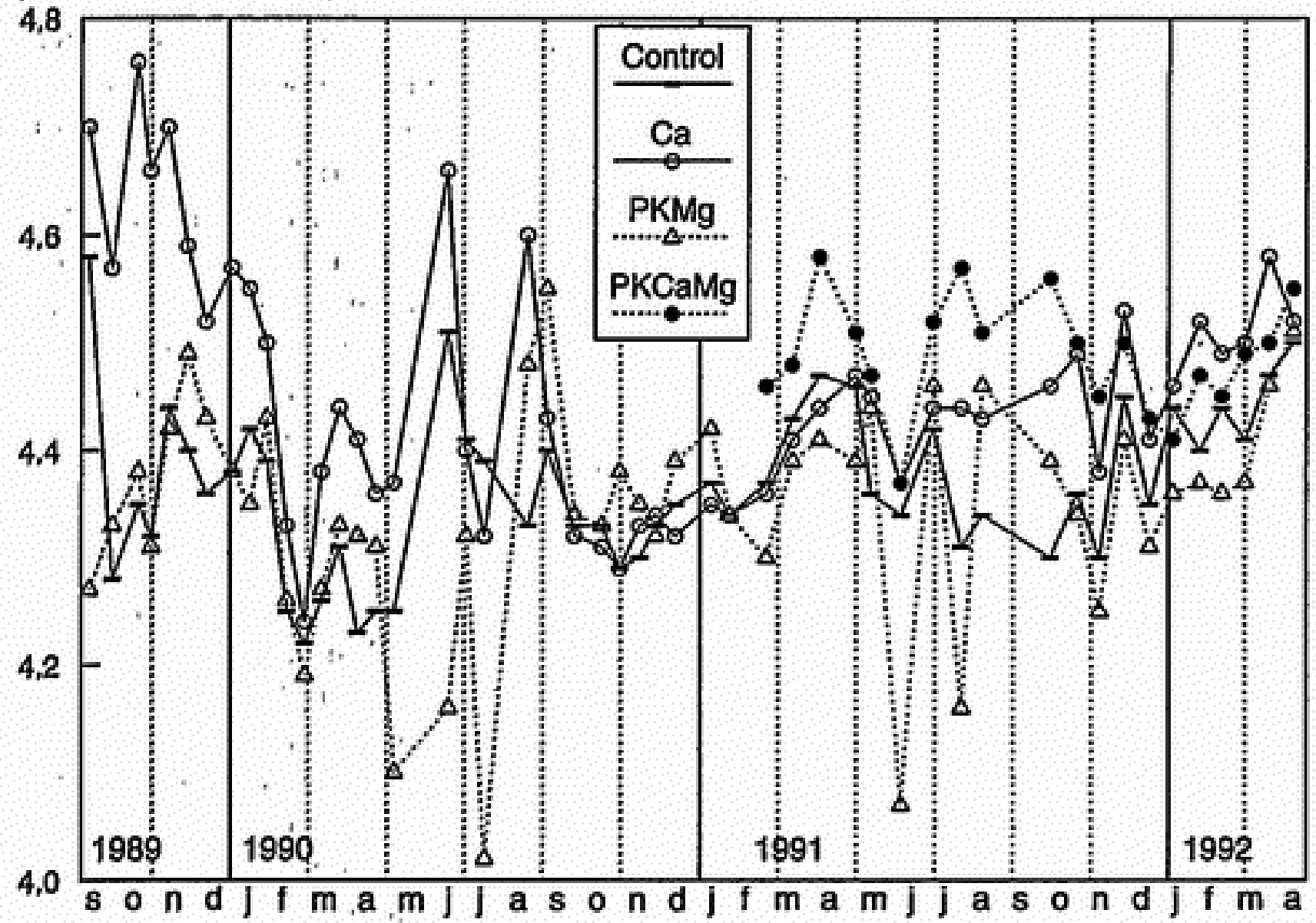

Fig, I. pll values in the soil solution at $30 \mathrm{~cm}$. 
ing to below the root zone. In the vegetative period microbial processes in the topsoil may be inhibited by drought while nutrient uptake from deeper soil layers may still proceed, causing lower $\mathrm{NO}_{3}$ concentrations. During the sampling period the $\mathrm{NO}_{3}$ peak concentrations grew higher each year and moved to an earlier date. The increasing peak concentrations may be due to a storm and subsequent thinning that occurred on 25 January and in summer 1990, respectively. Vitousek et al. (1979) pointed out that tree harvesting may lead to increased $\mathrm{NO}_{3}$ concentrations in the soil solution, if the soil processes that prevent $\mathrm{NO}_{3}$ accumulation and transport are saturated. When mineralization is stimulated in canopy gaps and at the same time less $\mathrm{NH}_{4}$ is taken up by roots, more substrate is made available to nitrification, and $\mathrm{NO}_{3}$ may accumulate. In a situation of a precipitation excess and reduced root uptake, $\mathrm{NO}_{3}$ is likely to be subjected to leaching since $\mathrm{NO}_{3}$ retention is governed by biological uptake and not by abiotic chemical processes (Johnson et al., 1986). Vitousek et al. (1979) reported increased lysimeter $\mathrm{NO}_{3}$ concentrations at least 1 year after making trenches in three different forests. In the present research, after May $1990 \mathrm{NO}_{3}$ concentrations quickly rose to much higher values than in 1989.

The most pronounced effects of liming on $\mathrm{NO}_{3}$ were visible in the 1990/91autumn/winter peaks in concentrations and amounts, but these effects diminished subsequently (Fig. 2). Although liming increased soil solution $\mathrm{NO}_{3}$ from the start of the measurement period on, the ecosystem disturbance in 1991 seemed to enhance this effect. The subsequent decline of the liming effect may have been caused by a naturally wearing off of the disturbance effect in combination with the gradual $\mathrm{pH}$ decrease at the limed plots (Fig. 1). Mid 1991 for the first time significantly increased $\mathrm{NO}_{3}$ concentrations were observed in the $\mathrm{PKMg}$ plots. This enhancing effect of PKMg on $\mathrm{NO}_{3}$ suggests that the nitrifying microflora developed an ability to profit from an improved nutrient availability. In a large number of acid forest soils Kriebitzsch (1978) found fairly good correlations between availability indices of $P$ and $\mathrm{K}+\mathrm{Ca}$ and net $\mathrm{NO}_{3}$ production, which showed that non-nitrifying soils had a low nutrient availability. However, this does not necessarily mean that supplying nutrients will directly raise nitrification. Sahrawat et al. (1985) found little effect of $P$ addition on in-vitro ammonification and nitrification, and adding $\mathrm{P}$ and lime had the same stimulating effect on mineralization as adding lime only. A soil microflora adapted to poor conditions may not have the potential to develop or increase nitrification as a response to a higher nutrient availability, or only do so after a lag-phase. Probably, the sampling period in the present experiment included the end of such a lag-phase.

In several acid forest soils in Germany, Davis (1990) found $\mathrm{NO}_{3}$ concentrations that at a $20-40-\mathrm{cm}$ depth ranged from undetectable to ca. $500 \mathrm{mmol} \mathrm{m}^{-3}$. Compared to this value, the $\mathrm{NO}_{3}$ concentrations in the present research are high, but in the same range as, or lower than those observed by many other workers in western Europe (c.g. Van Breemen et al., 1987; Kreutzer et al, 1991; Marschner et al., 1991). In the Netherlands large quantities of atmospheric $\mathrm{N}$ are deposited, so that high $\mathrm{NO}_{3}$ concentrations can be expected. The rapid increase in $\mathrm{NO}_{3}$ concentrations after a relatively small disturbance as windfelling (see above) also indicates a high $\mathrm{N}$ status (Gundersen \& Rasmussen, 1990). The term 'nitrogen saturation' is often used for 
such situations, but it is not yet consistently defined (Skeffington, 1990; Tietema, 1992; Wright et al., 1991).

$\mathrm{NH}_{1}, \mathrm{NH}_{4}$ was usually present in low concentrations relative to $\mathrm{NO}_{3}$ (Fig. 3). Treatment effects were inconsistent and rarely significant. The peak concentrations of $\mathrm{NH}_{4}$ in both summer seasons coincided with dry periods, when only few cups could be sampled. These peaks may be due to increased mineralization during periods with high temperatures, but more likely they are due to water readily running though the dry soil during summer showers. The $\mathrm{NH}_{4}$ concentrations are in the same range as those found by Davis (1990) in Germany and New Zealand.

$K$ and $M g$. The concentrations of $\mathrm{K}$ (Fig. 4 ) and $\mathrm{Mg}$ (Fig. 5) were persistently increased due to fertilization up to the last sampling date, which was ca. 4 years after the final PKMg application (Table 2). $\mathrm{K}$ was applied in a soluble form and seemed to be readily washed out of the forest floor (Arnold \& van Diest, 1993a). Therefore, it is likely that in the long run increased $\mathrm{K}$ in the soil solution was caused by $\mathrm{K}$ recycling (c.f. Arnold \& van Diest, 1993b), e.g. canopy leaching and K release from needle litter. Because Mg was better retained in the forest floor (Arnold \& van Diest, 1993a), both a direct fertilization effect and a turnover effect may have played a role in sustaining an increased $\mathrm{Mg}$ availability.

$\mathrm{Al}$ and $\mathrm{Ca}$. The Al concentrations measured in the growing season of 1991 were lowcred by liming and increased by PKMg (Table 3), but only at $1 / 7 / 91$ these effects were significant, Van Grinsven et al. (1989), using a simulation model, predicted that additions of $\mathrm{K}$ and $\mathrm{Mg}$ (as sulphates) in a December-month would cause dramatically increased $\mathrm{Al}$ concentrations in the soil solution at $40 \mathrm{~cm}$ in the following year.

Table 3. Coneenirations of $\mathrm{Ca}$ and $\mathrm{Al}$ in the soil solution at a $30 \mathrm{~cm}$ depth at 3 dates in 1991 . The effects of liming on $\mathrm{Ca}$ were highly significant. $\mathrm{Cl}$ ratio $=$ concentration $/ \mathrm{Cl} \times 1000$.

\begin{tabular}{|c|c|c|c|c|c|c|c|c|}
\hline \multirow[t]{2}{*}{ Element } & \multirow{2}{*}{\multicolumn{2}{|c|}{ Treatment }} & \multicolumn{3}{|c|}{$\mathrm{mmol} \mathrm{m}^{-3}$ at 3 dates } & \multicolumn{3}{|c|}{$\mathrm{Cl}$ ratio at 3 dates } \\
\hline & & & $14 / 5$ & $1 / 7$ & $8 / 8$ & $14 / 5$ & $1 / 7$ & $8 / 8$ \\
\hline $\mathrm{Ca}$ & $\begin{array}{l}\text { Contrul } \\
\text { PKMg } \\
\text { Ca } \\
\text { PKCaMg }\end{array}$ & & $\begin{array}{r}35 \\
85 \\
592 \\
354\end{array}$ & $\begin{array}{r}21 \\
54 \\
416 \\
493\end{array}$ & $\begin{array}{r}26 \\
99 \\
296 \\
375\end{array}$ & $\begin{array}{r}46 \\
110 \\
951 \\
422\end{array}$ & $\begin{array}{r}142 \\
164 \\
1944 \\
973\end{array}$ & $\begin{array}{r}105 \\
177 \\
1123 \\
1072\end{array}$ \\
\hline Al & $\begin{array}{l}\text { Control } \\
\text { PKMg } \\
\mathrm{Ca} \\
\text { PKCaMg }\end{array}$ & $\begin{array}{r}2 \\
+\end{array}$ & $\begin{array}{l}274 \\
521 \\
172 \\
289\end{array}$ & $\begin{array}{l}183 \\
373 \\
149 \\
234\end{array}$ & $\begin{array}{r}189 \\
546 \\
98 \\
225\end{array}$ & $\begin{array}{l}404 \\
594 \\
337 \\
230\end{array}$ & $\begin{array}{l}995 \\
956 \\
749 \\
401\end{array}$ & $\begin{array}{l}808 \\
638 \\
290 \\
348\end{array}$ \\
\hline $\mathrm{Ca} / \mathrm{Al}$ & $\begin{array}{l}\text { Control } \\
\text { PKMg } \\
\text { Ca } \\
\text { PKCaMg }\end{array}$ & & $\begin{array}{l}0.1 \\
0.2 \\
5.7 \\
2.2\end{array}$ & $\begin{array}{l}0.1 \\
0.2 \\
4.1 \\
3.1\end{array}$ & $\begin{array}{l}0.1 \\
0.3 \\
5.5 \\
3.9\end{array}$ & $\cdots$ & & \\
\hline
\end{tabular}




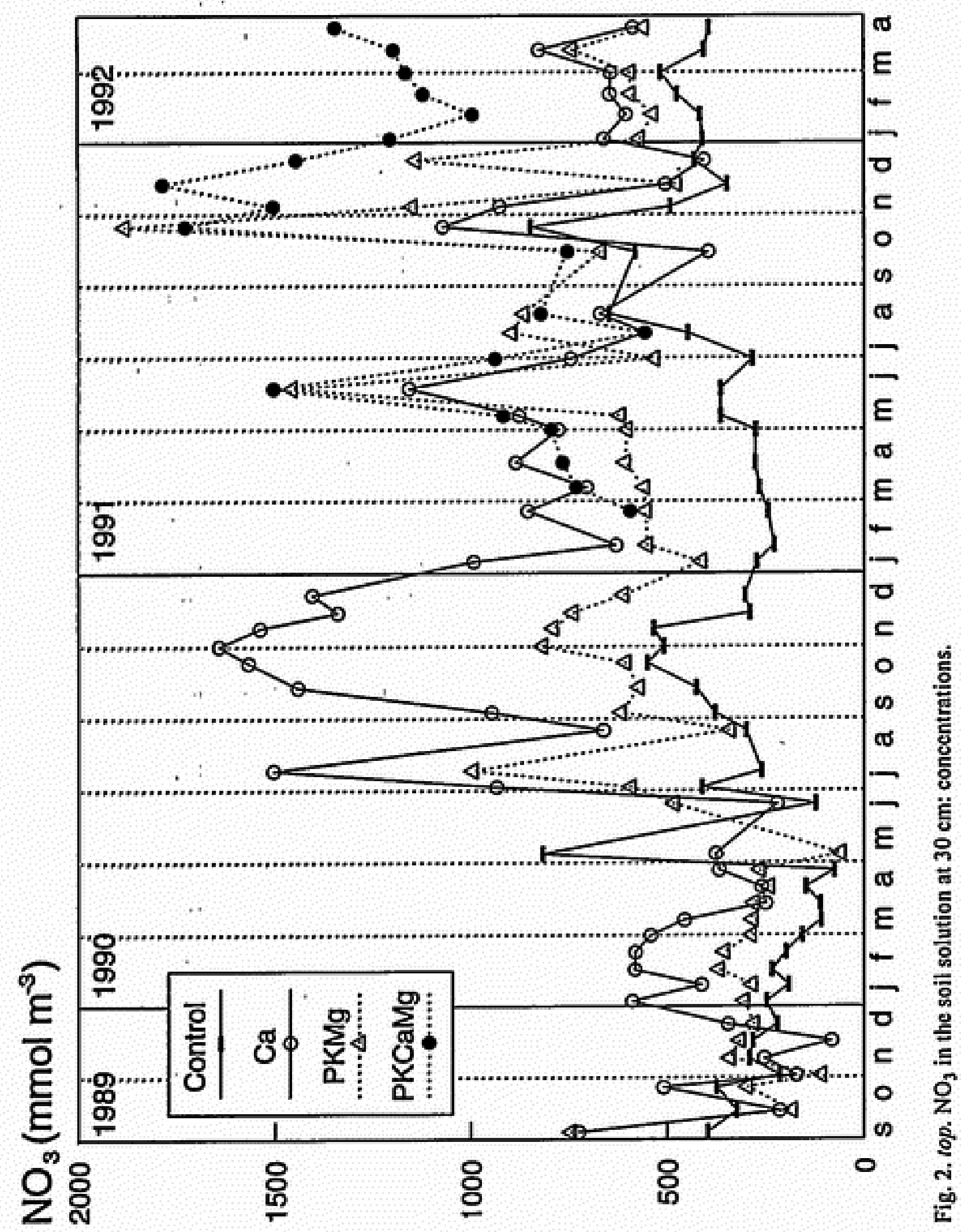


RESPONSE OF A SCOTS PINE STAND TO FERTILIZATION. 2.

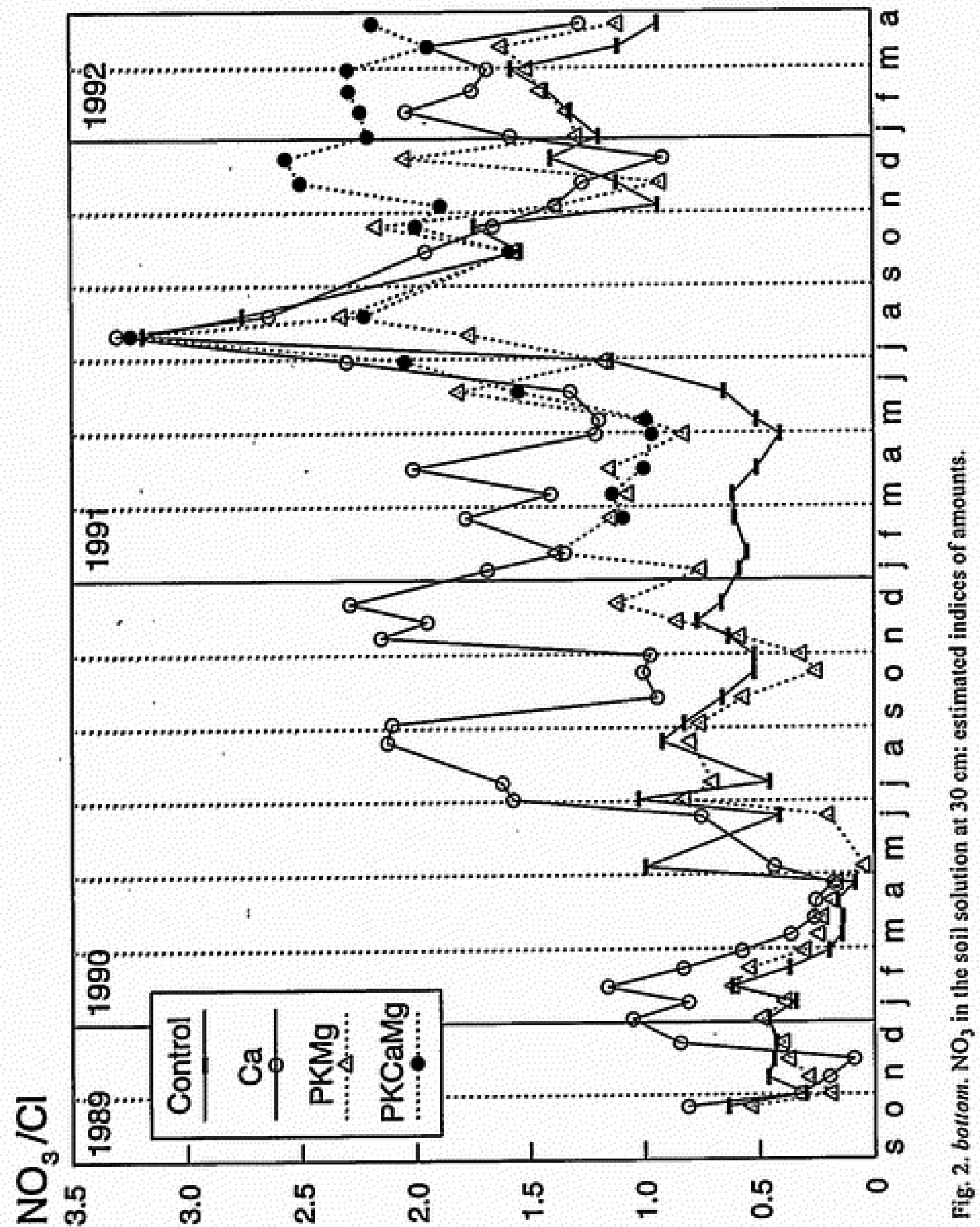


G. ARNOLD, I.L. SWEERS AND A. VAN DIEST

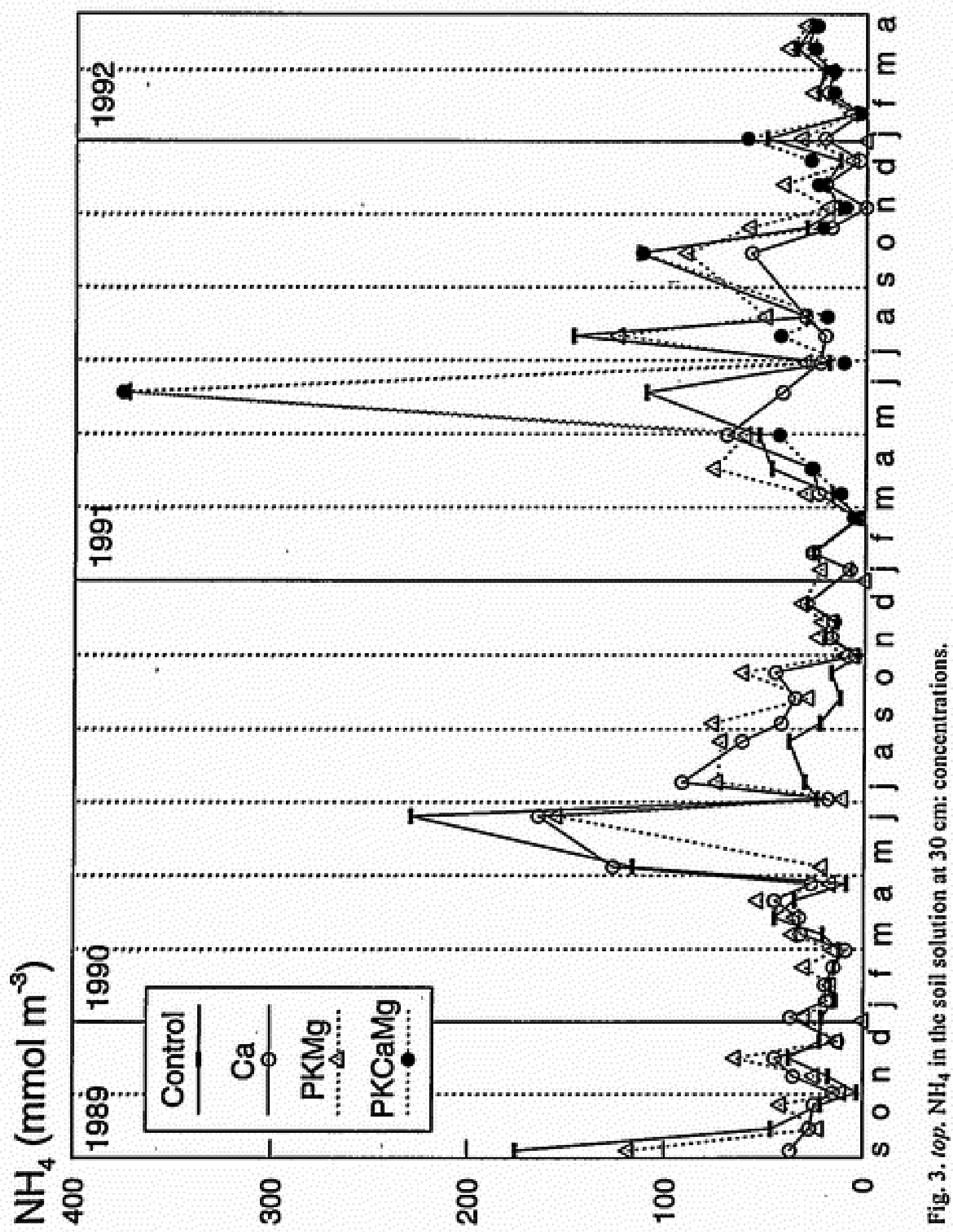


RESPONSE OF A SCOTS PINE STAND TO FERTILIZATION. 2.

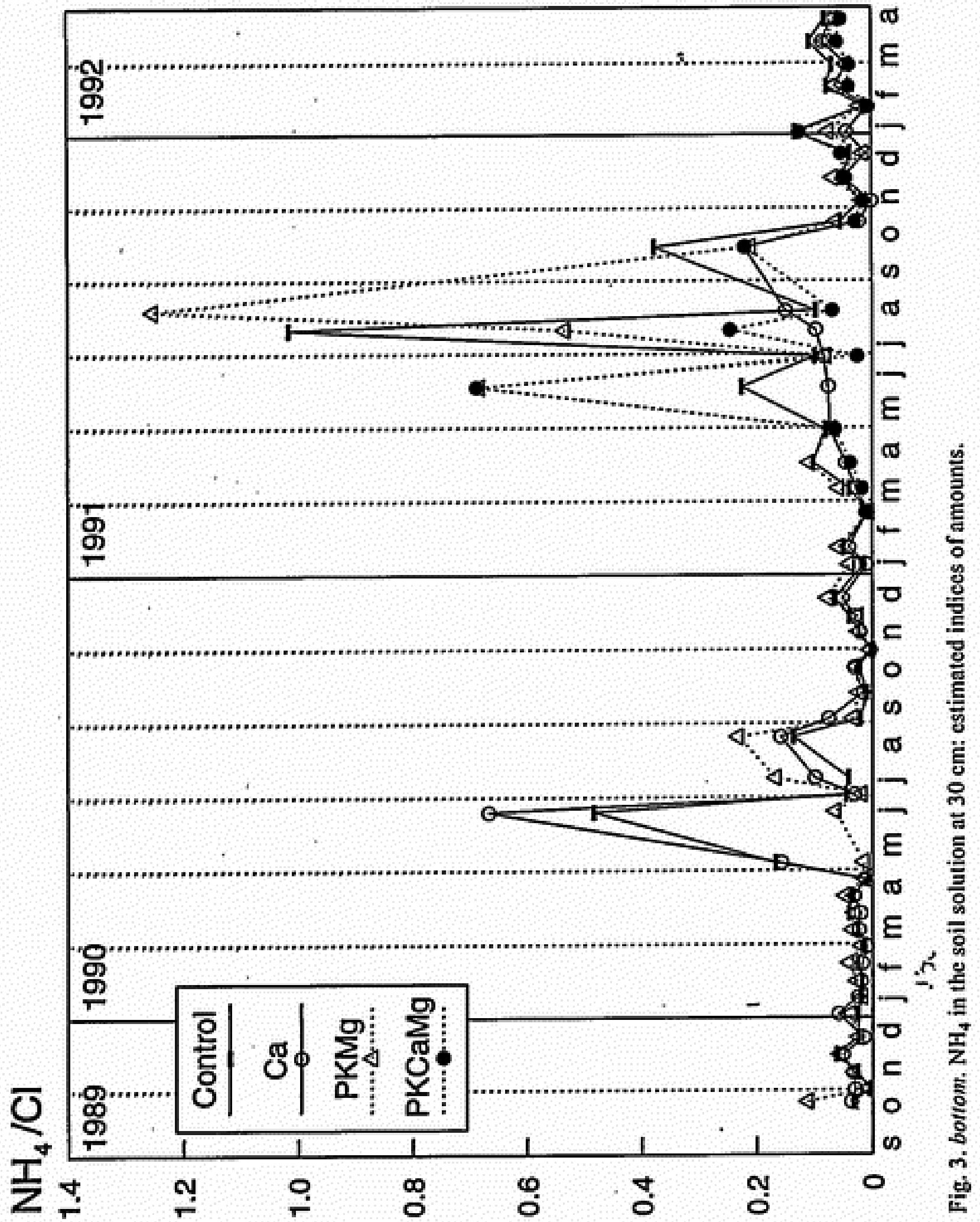

Netherlands Journal of Agricultural Science 41 (1993) 


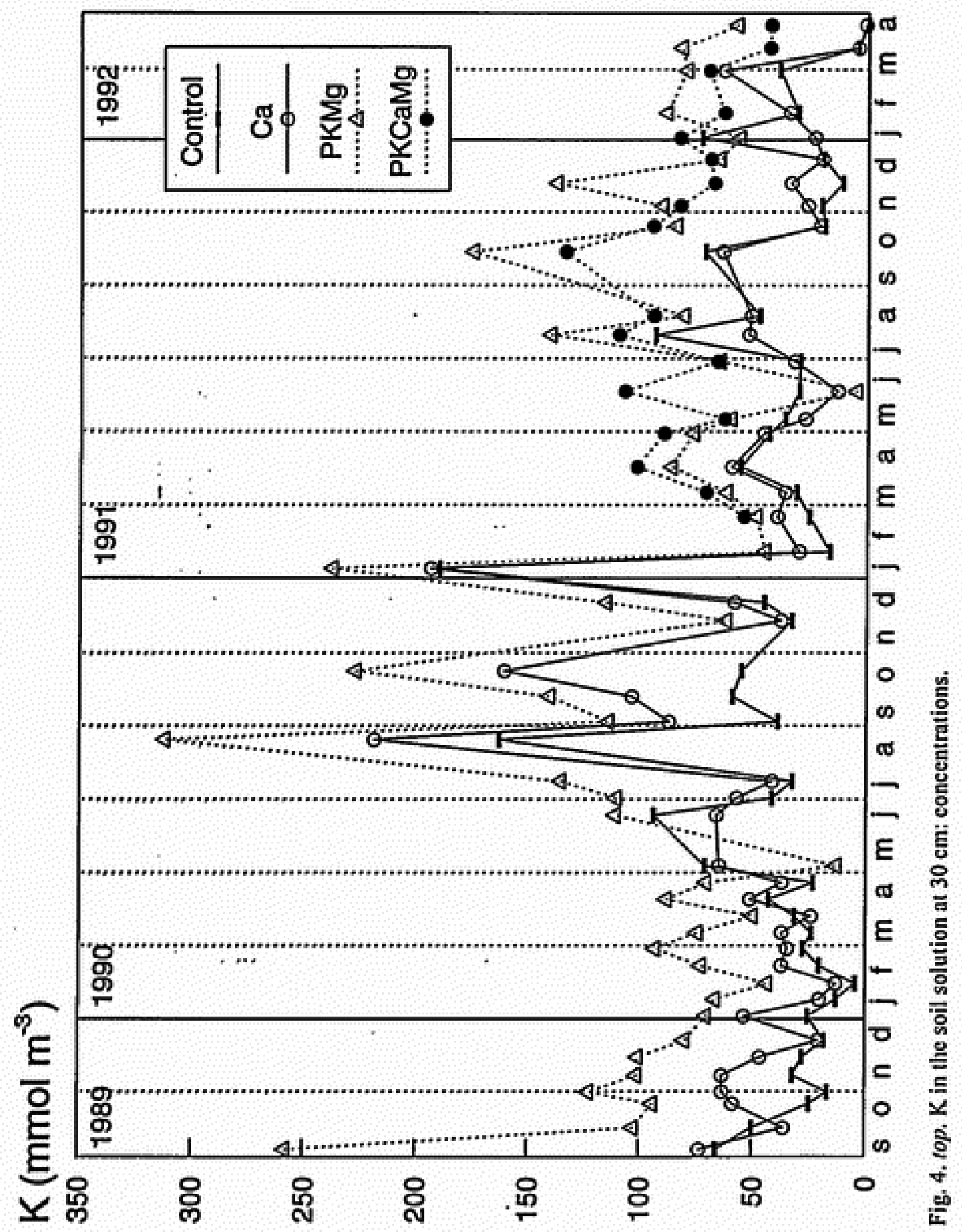


RESPONSE OF A SCOTS PINE STAND TO FERTILIZATION. 2.

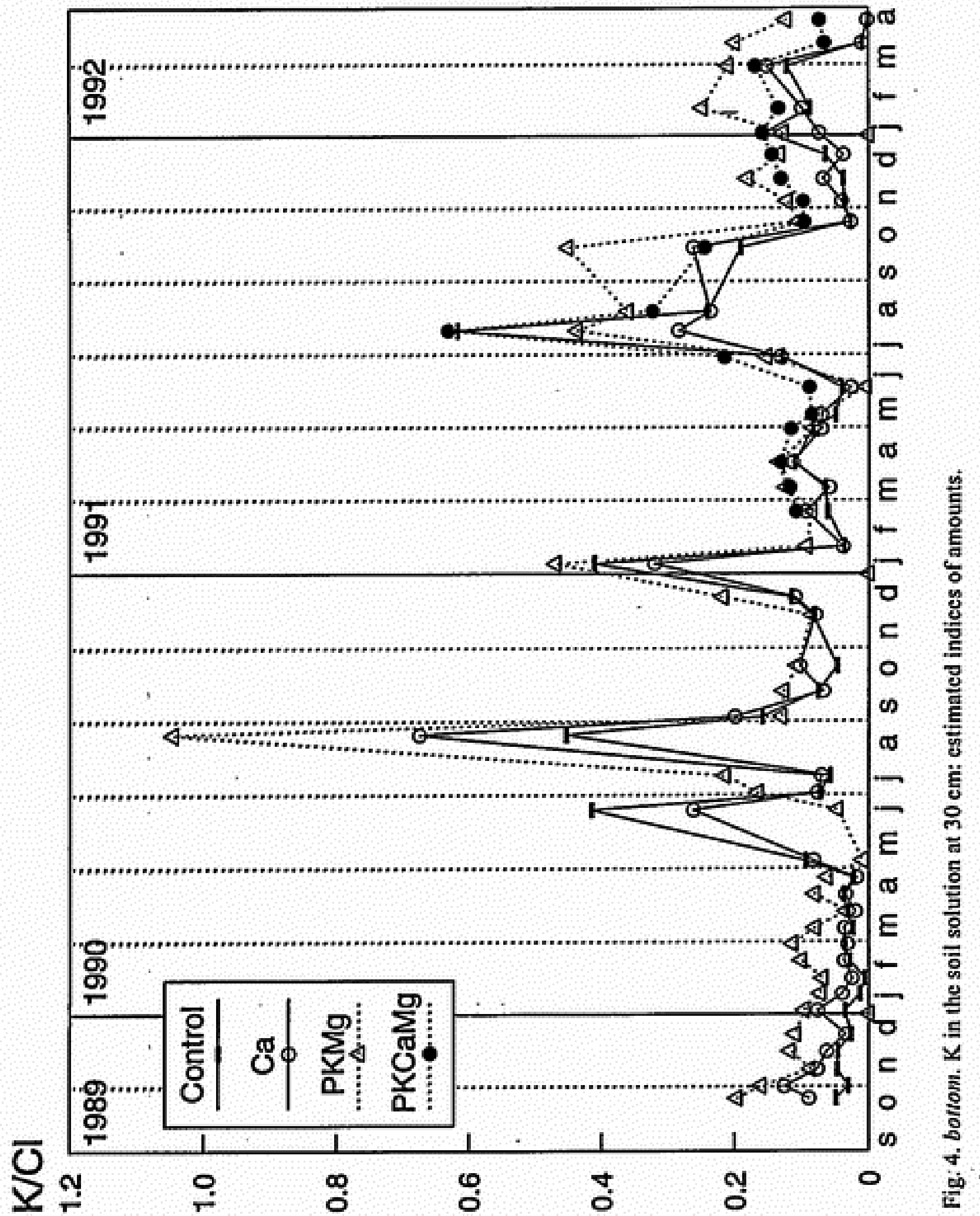

Netherlands Journal of Agricultural Science 41 (1993) 


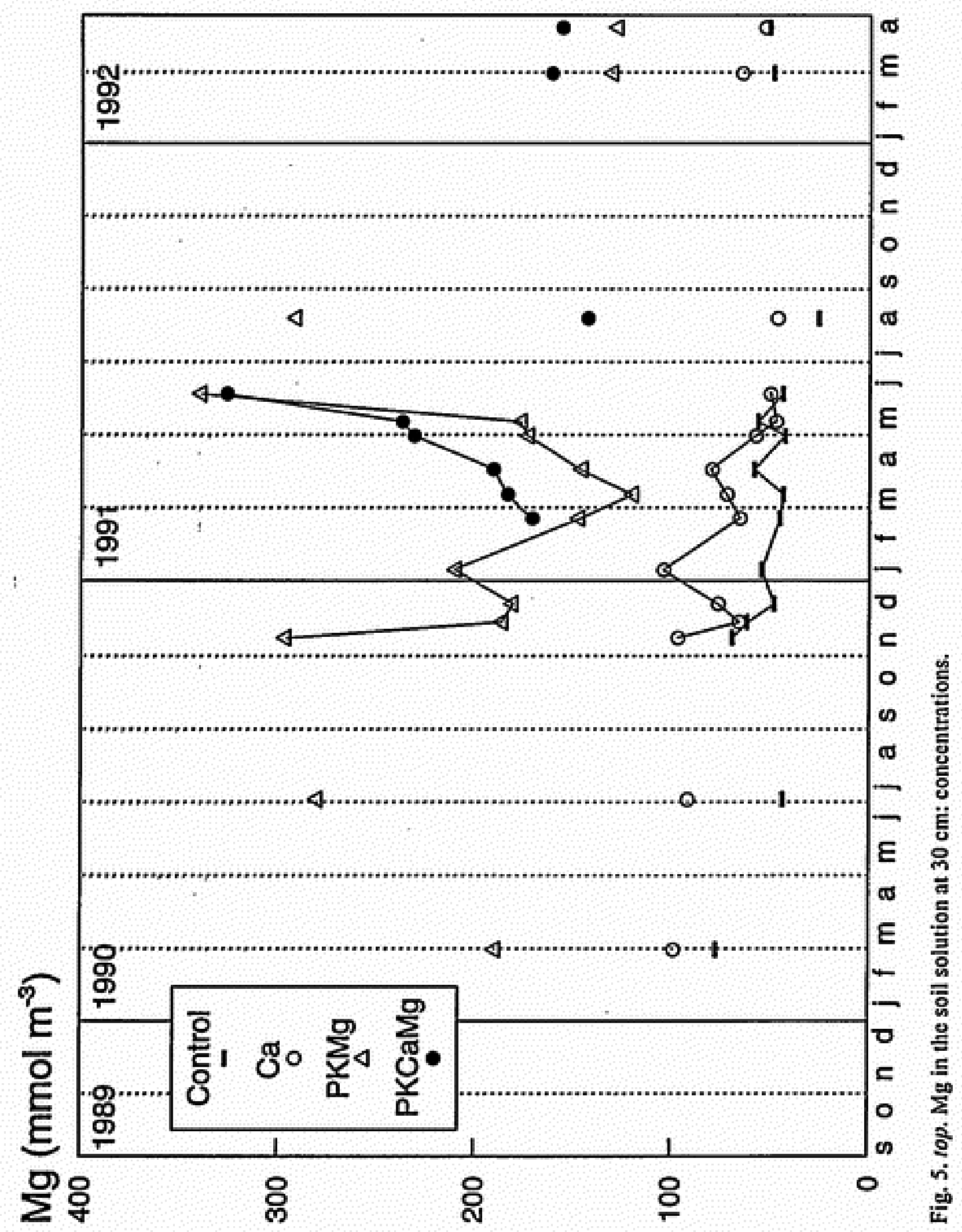


RESPONSE OF A SCOTS PINE STAND TO FERTILIZATION. 2.

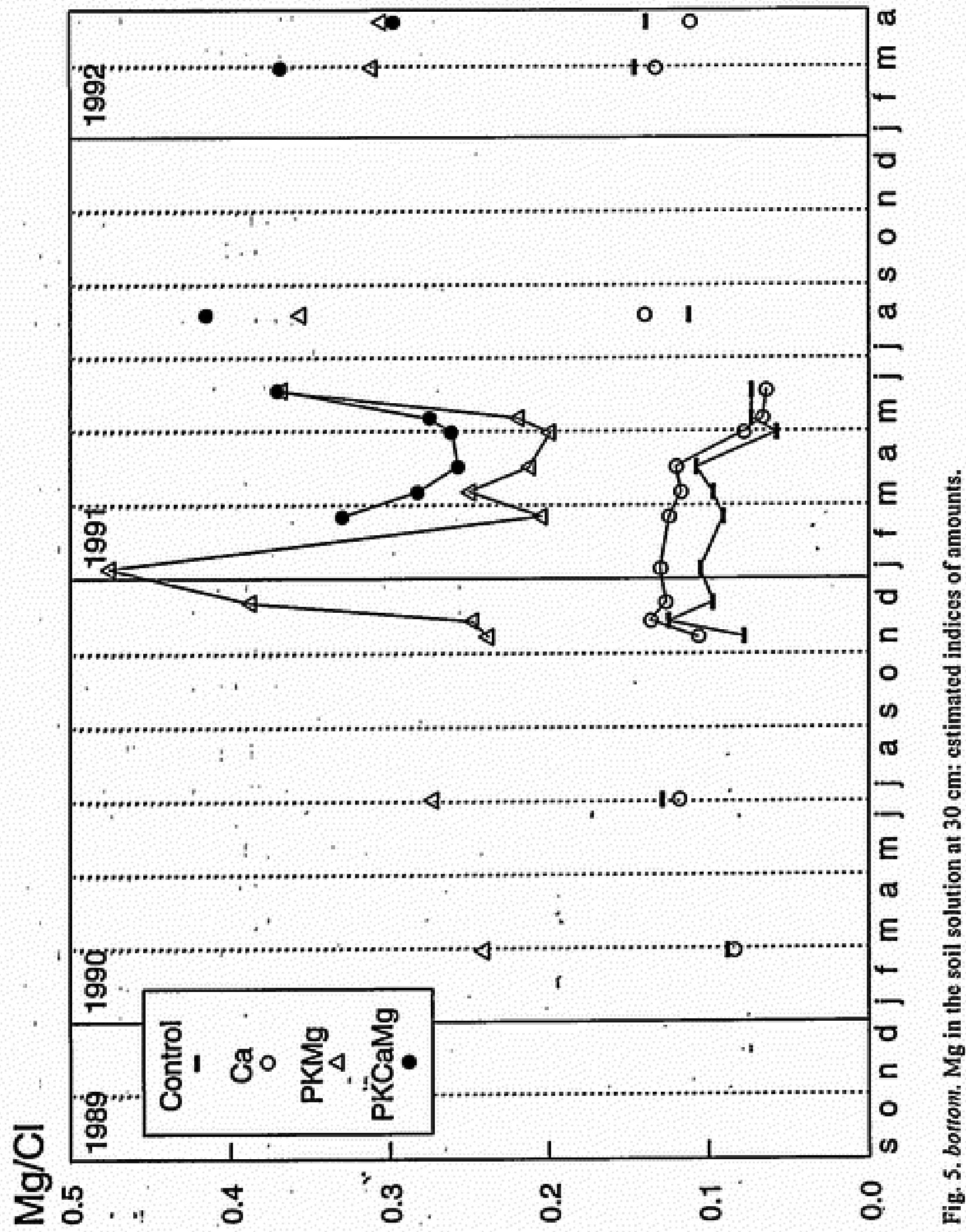

Netherlands Journal of Agricultural Science 4 I (1993) 
However, the model was calibrated for a different location. The actual $\mathrm{Al}$ peak in Harderwijk may have covered a longer period, which will probably have made it less extreme. In such a case, the eventual effect may be more harmful than that of a short and intense peak. However, the observed $\mathrm{Al}$ concentrations (Table 3 ) are lower than those known to impair Scots pine seedling roots, which are generally mentioned to be $>1 \mathrm{~m} M$, (Arovaara and Ilvesniemi, 1990; Keltjens and Van Loenen, 1989; Eldhuset et al,, 1987). Al tolerance may even be higher when ectomycorrhizae are present (Göransson and Eldhuset, 1990), which is the case in the present experiment (Kuyper, 1990). On the other hand, at the unlimed plots the Ca:Al ratios may be critical (Table 3). Ca:Al ratios < 0.2 are suspected to cause root damage in spruce (Ulrich, 1983).

\section{Soll solution composition at $100-150 \mathrm{~cm}$ depth}

In April 1989, Denier van der Gon (1990) analyzed the soil solutions at a 100-150 $\mathrm{cm}$ depth in the Control and PKMg treatments and in plots that had been treated with $6000 \mathrm{~kg}$ lime $\mathrm{ha}^{-1}$ and $\mathrm{P}, \mathrm{K}$ and $\mathrm{Mg}$ according to Table 2. For comparison with the present data, his results were reprocessed. Median instead of mean concentrations per plot were calculated after which significance of treatment effects was assessed using the REGWF test. Therefore, the data given here (Table 4) differ slightly from those published earlier (Denier van der Gon, 1990).

$\mathrm{NO}_{3}$ and $\mathrm{NH}_{4}$. The present observations (Table 5) show increased $\mathrm{NO}_{3}$ leaching after liming, as was expected (see above). On an average, liming doubled the $\mathrm{NO}_{3}$ concentrations (Table 5). With an assumed soil moisture content of $10 \%(w / w)$, in the 100 $150 \mathrm{~cm}$ layer of the limed plots compared to the unlimed plots an additional amount of ca, $4.5 \mathrm{~kg} \mathrm{NO}_{3}-\mathrm{N} \mathrm{ha}^{-1}$ was present below the root zone. Taking the present concentrations as annual averages, a precipitation excess of $200 \mathrm{~mm} \mathrm{y}^{-1}$ would effect a $\mathrm{NO}_{3}$ leaching of ca. 9 and $21 \mathrm{~kg} \mathrm{~N} \mathrm{ha}^{-1} \mathrm{y}^{-1}$ in the unlimed and limed plots, respectively. These amounts are lower than those found to leach to a 22-cm depth in an insitu incubation experiment carried out at the same site (Arnold et al., 1993). This, and the fact that the $\mathrm{NO}_{3}$ concentrations at $30 \mathrm{~cm}$ are higher than at $100-150 \mathrm{~cm}$ suggest that the trees absorb $\mathrm{NO}_{3}$ from soil segments deeper than ca. $30 \mathrm{~cm}$. Denitrification probably played not more than a minor role in this well-aerated sandy soil (Grofman \& Tiedje, 1989). The annual N deposition in the region where the experiment was conducted amounts to approx. $30 \mathrm{~kg} \mathrm{NH}_{4}-\mathrm{N}_{\text {and }} 10 \mathrm{~kg} \mathrm{NO}_{3}-\mathrm{N} \mathrm{ha}^{-1}$ (Beier \& Rasmussen, 1993). Thus, total $\mathrm{N}$ deposition is higher than the estimated quantities of $\mathrm{N}$ annually lost due to $\mathrm{NO}_{3}$ leaching. $\mathrm{NH}_{4}$ leaching could not be estimated, but was probably-negligible. In a pine forest in Germany with throughfall depositions of $\mathrm{NH}_{4}$ and $\mathrm{NO}_{3}$ almost identical to those mentioned above, Van.Grinsven et al. (1991) found $\mathrm{NO}_{3}$ fluxes at.a $1 \mathrm{~m}$ depth amounting to ca. $17 \mathrm{~kg} \mathrm{~N} \mathrm{ha}^{-1} \mathrm{y}^{-1}$, whereas $\mathrm{NH}_{4}$ did not leach to that depth.

In 1989 no effect of-liming-on. $\mathrm{NO}_{3}$ was found (Table-4), which was due to the high $\mathrm{NO}_{3}$ concentrations in the unlimed plots in 1989, relative to those in 1991 (Table 5). This may be a result of a higher mineralization and/or nitrification, a low- 
Table 4, Median concentrations of elements in the soil solution at a $100-150 \mathrm{~cm}$ depth in several experimental plots with Seots pine in April 1989 (from: Denier van der Gon, 1990).

\begin{tabular}{|c|c|c|c|c|c|c|c|c|c|}
\hline \multirow{2}{*}{ Trentment } & \multirow{2}{*}{ 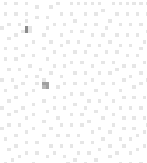 } & \multicolumn{8}{|c|}{$\mathrm{mmol} \mathrm{m}^{-3}$} \\
\hline & & $\mathrm{NH}_{4}$ & $\mathrm{NO}_{3}$ & $\mathbf{K}$ & $\mathrm{Ca}$ & $\mathrm{Mg}$ & Al & $\mathrm{Cl}$ & $\mathrm{SO}_{4}$ \\
\hline $\begin{array}{l}\text { Control } \\
\text { PKMg } \\
\text { PKMg }+60\end{array}$ & ime ha- & $\begin{array}{r}85 \mathrm{a}^{2} \\
119 \mathrm{a} \\
27 \mathrm{a}\end{array}$ & $\begin{array}{l}518 \mathrm{a} \\
422 \mathrm{a} \\
599 \mathrm{a}\end{array}$ & $\begin{array}{r}53 \mathrm{a} \\
106 \mathrm{a} \\
52 \mathrm{a}\end{array}$ & $\begin{array}{l}141 \mathrm{a} \\
192 \mathrm{a} \\
646 \mathrm{~b}\end{array}$ & $\begin{array}{l}102 \mathrm{a} \\
466 \mathrm{~b} \\
375 \mathrm{~b}\end{array}$ & $\begin{array}{l}151 \text { a } \\
206 \text { a } \\
134 \text { a }\end{array}$ & $\begin{array}{l}642 \mathrm{a} \\
708 \mathrm{a} \\
623 \mathrm{a}\end{array}$ & $\begin{array}{r}317 \mathrm{a} \\
832 \mathrm{~b} \\
1027 \mathrm{~b}\end{array}$ \\
\hline
\end{tabular}

${ }^{x}$ Averages followed by a common letter are not significantly different (REGWF test at $P=0.05$ ).

Table 5, Median concentrations of elements in the soil solution at a $100-150 \mathrm{~cm}$ depth in several experimental plots with Scots pine in April/May 1991.

\begin{tabular}{|c|c|c|c|c|c|c|c|c|}
\hline \multirow{2}{*}{ Treatment } & \multicolumn{8}{|c|}{$\mathrm{mmol} \mathrm{m}^{-3}$} \\
\hline & NiH4, & NO3 & & $\mathbf{K}$ & $\mathrm{Ca}$ & Mg & Al & $\mathrm{Cl}$ \\
\hline $\begin{array}{l}\text { Control } \\
\text { PKMg } \\
\mathrm{Cn} \\
\text { PKCaMg }\end{array}$ & $\begin{array}{l}61 \\
84 \\
97 \\
76\end{array}$ & $\begin{array}{l}250 \\
405 \\
826 \\
669\end{array}$ & . & $\begin{array}{r}85 \\
181 \\
101 \\
142\end{array}$ & $\begin{array}{l}238 \\
312 \\
484 \\
607\end{array}$ & $\begin{array}{l}110 \\
320 \\
173 \\
306\end{array}$ & $\begin{array}{l}47 \\
57 \\
48 \\
51\end{array}$ & $\begin{array}{r}1006 \\
1107 \\
895 \\
1025\end{array}$ \\
\hline \multicolumn{9}{|c|}{$P$ values per treatmenit (dashes: $P>0: 10$ ): } \\
\hline $\begin{array}{l}\mathrm{Ca} \\
\text { PKMg } \\
\mathrm{Cn} \times \mathrm{PKMg}\end{array}$ & $\begin{array}{l}- \\
\overline{0} \\
0.06\end{array}$ & $\begin{array}{l}0.00 \\
- \\
-\end{array}$ & 08 & $\begin{array}{l}- \\
0.001 \\
0.05\end{array}$ & $\begin{array}{l}0.0001 \\
0.003 \\
-\end{array}$ & $\begin{array}{l}- \\
0.0002 \\
-\end{array}$ & $\begin{array}{l}- \\
-\end{array}$ & - \\
\hline
\end{tabular}

er $\mathrm{N}$ uptake, or both, in 1988 than in 1990. Because the relatively moist summer conditions in 1988 were favourable for Scots pine growth (Arnold \& van Diest, 1993b), it is likely that tree $\mathrm{N}$ uptake was stimulated, rather than reduced. But mineralization and nitrification were probably more stimulated than tree uptake, because microbial processes can more readily respond to changing external conditions. Further, the $\mathrm{NO}_{3}$ concentrations at $30 \mathrm{~cm}$ showed a pronounced difference between the limed and unlimed plots at the end of 1990 (Figure 2), which may be a reason that in spring 1991 a liming effect was observed in the subsoil. Marschner et al. (1989) found rather steady $\mathrm{NO}_{3}$ concentrations of ca. $140 \mathrm{mmol} \mathrm{m}^{-3}$ at a $2 \mathrm{~m}$ depth in the control plot of a Scots pine liming experiment. A sharp increase to ca. $800 \mathrm{mmol} \mathrm{m}^{-3}$ was observed 6 months after liming and a gradual decrease to ca. $280 \mathrm{mmol} \mathrm{m}^{-3}$ in the subsequent 2 y. ... i

There were no significant effects of $\mathrm{PKMg}$ on the $\mathrm{NO}_{3}$ concentrations (Table 5) because at the time of sampling these effects just started to appear in the topsoil (see above).

It is unusual to find higher $\mathrm{NH}_{4}$ soil solution concentrations in the subsoil than in the topsoil (Table 5, Figure 3). But the measured $\mathrm{NH}_{4}$ concentrations were probably too high, because the filters that were used during the centrifugation contained $\mathrm{NH}_{4}$. 
However, as this contamination was probably systematic, comparison of treatments is still valid, which shows no significant main effects and a weak CaxPKMg interaction (Table 5). The centrifugation procedure of the 1989 samples was similar to that of the present research, and may also have caused a systematic $\mathrm{NH}_{4}$ contamination. The data suggest that liming lowered the $\mathrm{NH}_{4}$ concentration in 1989 (Table 4), but the effect was not significant (overall $\mathrm{F}$ test: $P=0.06$ ). Lowering of $\mathrm{NH}_{4}$ in the soil solution by liming was not expected, because in this Scots pine stand liming increased $\mathrm{N}$ mineralization, but not the proportion of mineralized $\mathrm{N}$ that was nitrified (Arnold et al., 1993).

$K$ and $\mathrm{Mg} . \mathrm{K}$ and $\mathrm{Mg}$ were significantly increased in the $\mathrm{PKMg}$-amended plots. With the assumptions mentioned above, the estimated additional annual leaching of $\mathrm{K}$ and $\mathrm{Mg}$ caused by fertilization would amount to 5 and $8 \mathrm{~kg} \mathrm{ha}^{-1}$, respectively. In 1989 these values were 4 and $18 \mathrm{~kg} \mathrm{ha}^{-1}$, respectively (recalculated from Denier van der Gon, 1990). The obvious conclusion that $\mathrm{Mg}$ is more susceptible to leaching than $\mathrm{K}$ is contradicted by previous results (Arnold \& van Diest, 1993a), which suggested a direct and complete loss of added $\mathrm{K}$ from the forest floor, while $\mathrm{Mg}$ was retained to some extent. With the present data the apparently lower $\mathrm{K}$ leaching is hard to explain, It can be speculated that large quantities of $\mathrm{K}$ leached deeper than $1.5 \mathrm{~m}$ within 1 year (after the final 1988 application). Marschner et al. (1989) found the maximum increase in $\mathrm{K}$ concentration in the soil solution at a $2 \mathrm{~m}$ depth only 2 months after $\mathrm{K}$ application on a sandy soil. Another explanation may be the larger crop demand for $\mathrm{K}$ than for $\mathrm{Mg}$.

$\mathrm{Al}$ and $\mathrm{Ca}$. The $\mathrm{Al}$ concentrations (Table 5) are low when compared to those in Table 4. In the present research a 3-fold dilution was used during the measurements, which may have caused an error. Unfortunately, this can not be verified any more from the original results. However, it is clear that $\mathrm{Al}$ was not influenced by any treatment, as was found earlier (Table 4). Marschner et al. (1989) found persistently increased Al concentrations in the soil solution at a $2 \mathrm{~m}$ depth in 2 years directly after additions of $\mathrm{K}_{2} \mathrm{SO}_{4}$ and lime, whereas those at $50 \mathrm{~cm}$ were only slightly raised for ca. 1 year. The Table 4 data were obtained 3 years after the second and last lime application ( 3000 $\mathrm{kg}$ lime ha $\mathrm{a}^{-1}$ ) in the $6000 \mathrm{~kg}$ lime treatment and 1 year after the 3rd and last $\mathrm{K}$ and $\mathrm{Mg}$ applications, in which time a possibly induced Al flush (Van Grinsven et al., 1989) may have passed beyond the $100-150 \mathrm{~cm}$ layer. The unaffected $\mathrm{Al}$ concentrations at $100-150 \mathrm{~cm}$ suggest that the observed increases at $30 \mathrm{~cm}$ in the $\mathrm{PKMg}$ plots (see above) are occasional. The seemingly lower $\mathrm{Al}$ concentration at the limed plots in Table 4 is not confirmed by later observations (Table 5).

Ca was significantly increased by liming in 1989 and 1991 (Tables 4 and 5). In 1991 the Ca concentration was also increased by PKMg (Table 5). This may be due to exchange processes, which created a $\mathrm{Ca}$ front that had not yet reached the $1 \mathrm{~m}$ depth in 1989 (Table 4). In 199.1, this effect was not found at $30 \mathrm{~cm}$ (Table 3), indicating that a new equilibrium had established. 


\section{Relatioinships between cation and anion concentrations}

To examine whether liming may have increased cation mobilization by an increased nitrification, multiple regression analysis of individual cation concentrations on anion concentrations was carried out with log-transformed data. Correlations between cation- and $\mathrm{NO}_{3}$ concentrations suggest the occurrence of this mobilization process (Mulder \& Van Breemen, 1987; Van Breemen \& Jordens, 1983).

In most cases positive correlations between cation- and $\mathrm{Cl}$ concentrations were found (Tables 6 and 7). These can be attributed to evaporation/dilution effects.

For $\mathrm{Mg}$ and especially for $\mathrm{K}$ at $30 \mathrm{~cm}$ poor correlations with anions were found and liming did not improve correlations with $\mathrm{NO}_{3}$ (Table 6). Generally, $\mathrm{Al}$ and $\mathrm{Ca}$ at $30 \mathrm{~cm}$ correlated better with $\mathrm{Cl}$ and/or $\mathrm{NO}_{3}$ than did $\mathrm{K}$ and $\mathrm{Mg}$. Liming caused $\mathrm{Al}$ to become correlated with $\mathrm{NO}_{3}$ (Table 6), indicating that in $1991 \mathrm{NO}_{3}$ played a role in Al mobilization in the topsoil of the limed plots. However, the latter was not paralleled in the deeper soil solution, where $\mathrm{Al}$ was correlated with $\mathrm{NO}_{3}$ irrespective of treatment, or where liming even cancelled this correlation (Table 7). Of the other cations in the soil solution at $100-150 \mathrm{~cm}$ only $\mathrm{Ca}$ in 1991 was correlated with $\mathrm{NO}_{3}$ as a consequence of liming (Table 7). It can thus be concluded that there is no direct evidence of liming to increase leaching of nutrient cations through the formation of nitric acid.

Table 6. Results of (multiple) regression of cation on anion concentrations in soil moisture at $30 \mathrm{~cm}$ sampled at two dates. Models with overall $P$ values $<0.05$ and $T$ values $<0.05$ for each anion; + : positive correlation; $(+)$ : regression model with slightly smaller $R^{2}$ value.

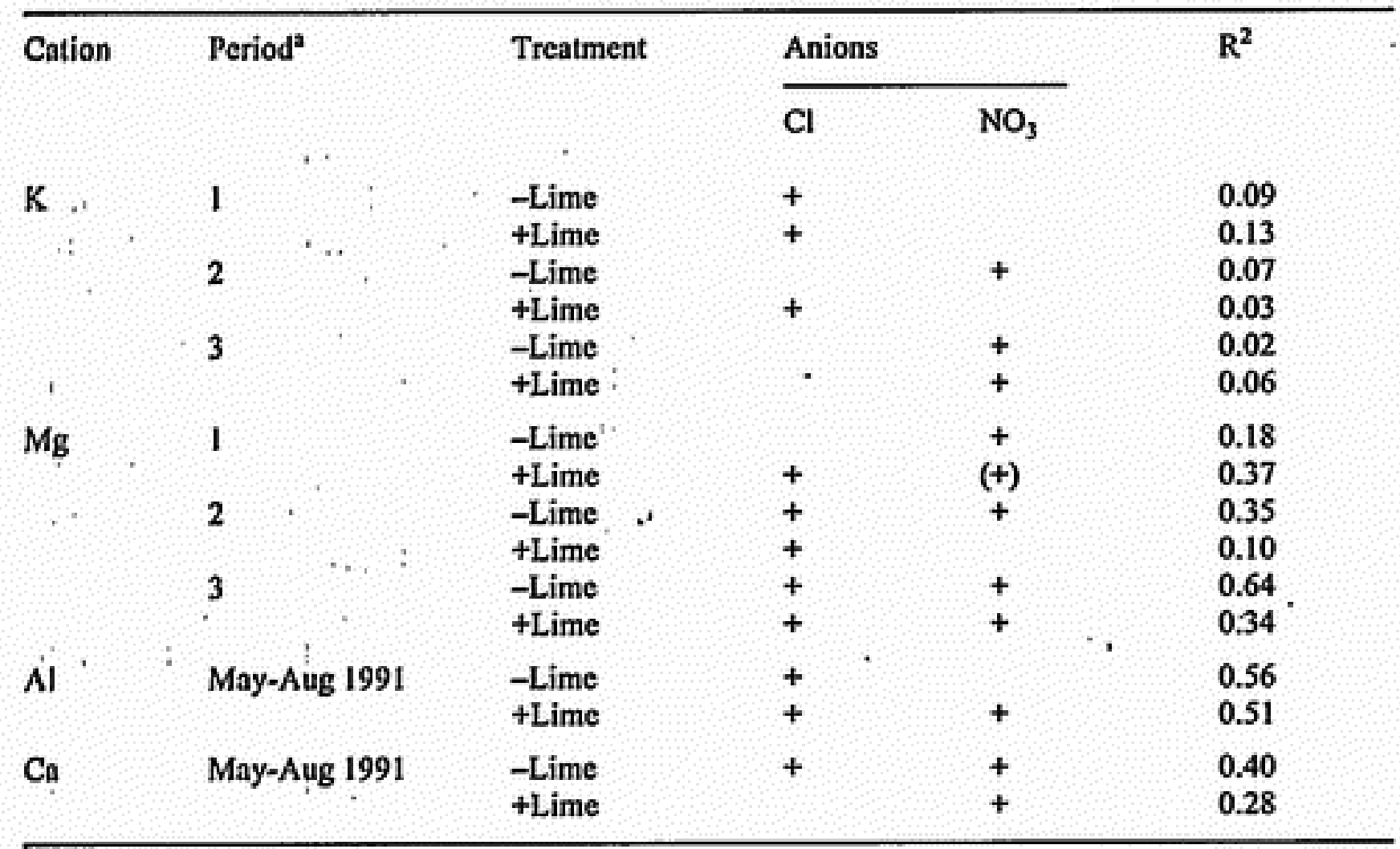

" 1 - Sept. 1989 - April 1990; 2 = April 1990 - April 1991;3 = April 1991 - April 1992. 
Table 7. Results of (multiple) regression of cation on anion concentrations in soil moisture at $100-150$ $\mathrm{cm}$ sampled at two dates. Models with overall $P$ values $<0.0002$ and $T$ values $<0.05$ for each anion; + : positive correlation; $(+)$ : (multiple) regression model with slightly smaller $\mathrm{R}^{2}$ value.

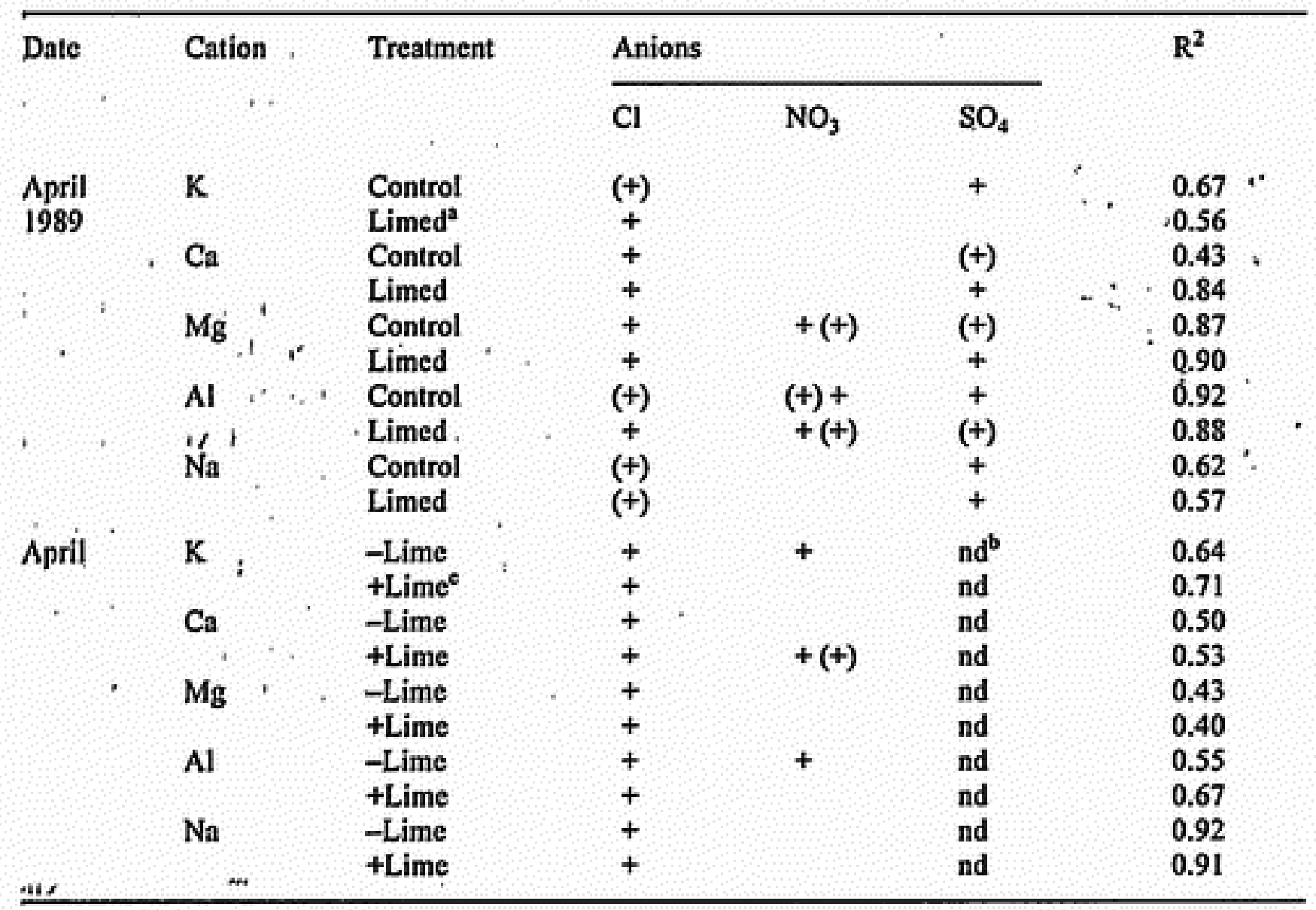

${ }^{9} 6000 \mathrm{~kg} \mathrm{lime} \mathrm{ha-1}{ }^{6}$ Not determined. ${ }^{\circ} 3000 \mathrm{~kg} \mathrm{lime} \mathrm{ha}{ }^{-1}$.

\section{Conclusions}

When Scots pine was treated with $\mathrm{P}, \mathrm{K}, \mathrm{Mg}$ and lime, the concentrations of each of the involved cations was increased in the soil solutions in the root zone. Consequently, the main objective of these applications, an increased nutrient availability and subsequent uptake by the trees, was realized, as was also shown by foliar analysis (Arnold \& van Diest, 1993b). Several treatments increased the soil solution concentrations of $\mathrm{K}, \mathrm{Ca}, \mathrm{Mg}, \mathrm{NO}_{3}$ and $\mathrm{SO}_{4}$ below the most densely rooted soil zone, indicating that these ions were subjected to leaching. Part of the increased leaching was due to the use of highly soluble $\mathrm{K}$ - and $\mathrm{Mg}$ sulphates. In the period 1988-1990, ca, $5 \%$ and $8-18 \%$ of the applied $\mathrm{K}$ and $\mathrm{Mg}$, respectively, annually leached to below a $1 \mathrm{~m}$ depth. Moreover, $\mathrm{K}$ leaching directly following application may have been considerable. Nevertheless, $\mathrm{K}$ was successfully incorporated in the biomass and strongly increased the trees' volume growth (Arnold \& van Diest, 1993b). This indicates that the applied amount of $\mathrm{K}$ greatly exceeded the uptake potential of the trees, and that little $\mathrm{K}$ was necessary for a considerable growth response.

When growth responses occur in a narrow range of nutrient availability, the use of slow-release fertilizers may be appropriate, because they reduce leaching. However, they are not necessarily always the proper choice. In principle, fertilizers should re- 
lease nutrients at a rate not higher than the expected maximum uptake rate during the growing season. A lower release rate may be beneficial, maintaining a continuous nutrient demand that keeps the nutrient pool in the soil solution at a low level until the end of the growing season and, thus, reduces subsequent nutrient leaching. In most cases, this will be accomplished by using slow-release fertilizers, but for fastgrowing tree species' or in stands before canopy closure easily soluble fertilizers may be necessary to meet the stand's nutrient requirements.

In the year following a heavy storm, $\mathrm{NO}_{3}$ concentrations reached maxima in the root zone of the plots that had received lime only (Fig. 2). This suggests that liming may corroborate $\mathrm{NO}_{3}$ leaching invoked by physical disturbance.

The often quoted hazard of liming to increase $\mathrm{NO}_{3}$ leaching appeared to possibly apply to fertilization as well. The former will occur in the short term, while the latter may be a long-term effect. Increased soil solution $\mathrm{NO}_{3}$ concentrations as a result of PKMg additions were measured from mid 1991 on at a $30 \mathrm{~cm}$, but not below a $1 \mathrm{~m}$ depth. In spite of an increased nitrification, the estimated annual $\mathrm{N}$ leaching was lower than the annual $\mathrm{N}$ deposition for each treatment, indicating that $\mathrm{N}$ is retained in the ecosystem and that a situation of ' $N$ saturation' is not (yet) reached.

\section{Acknowledgements:}

The National Institute of Public Health and Environmental Protection (RIVM) provided a travel grant. H.A.C. Denier van der Gon is thanked for releasing original research data.

\section{References}

Anonymous, 1990. Final Report - Commission on Forest Fertilization Recommendations. (In Dutch). Ministry of Agriculture, (former) Department of Forestry and Landscaping, Report no. 1990-11, 63 $\mathrm{pp}$.

Arnold, G., M.L. van Beusichem \& A. van Diest, 1993. Nitrogen mineralization and $\mathrm{H}^{+}$transfers in the forest floor and mineral soil of a Scots pine (Pinus sylvestris L.) forest, as measured by the ion exchange resin core techniquc. Plant and Soil (Submitted).

Arnold, G, \& A, van Diest, 1993a. Response of a Scots pine (Pinus sylvestris) stand to application of phosphorus, potassium, magnesium and lime. I. Soil data. Netherlands Journal of Agricultural Science 41: 247-265.

Arnold, G, \& A, van Diest, 1993b. Response of a Scots pine (Pinus sylvestris) stand to application of phosphorus, potassium, magnesium and lime. III. Foliar nutrient concentrations and stand development. Netherlands Journal of Agricultural Science 41: 291-307.

Arovaara, H. \& H.Ilvesniemi, 1990. Effects of soluble inorganic aluminum on the growth and nutrient concentrations of Pimus sylvestris and Picea abies seedlings. Scandanavian Journal of Forest Research 5; 49-58.

Beier, C. \& L.Rasmussen (eds.), 1993. EXMAN - Experimental Manipulation of Forest Ecosystems in Burope, European Communities Environmental Research Programme, Ecosystem Research Report no. 6. In press.

Bolt, G.H, \& M.G.M. Bruggenwert, 1978. Composition of the soil. In: G.H. Bolt \& M.G.M. Bruggenwert (eds.), Soil Chemistry - A. Basic elements, 2nd edition, p. 1-12. Elsevier, Amsterdam.

Davis, M.R., 1990. Chemical composition of soil solutions extracted from New Zealand beech forests and West German beech and spruce forests. Plant and Soil 126: 237-246.

Denier van der Gon, H.A.C., 1990. Soil Solution and Ground Water Composition under Forest Liming 


\section{G. ARNOLD, I.L. SWEERS AND A. VAN DIEST}

and Fertilization Plots in Harderwijk and St. Anthonis. (In Dutch). National Institute of Public Health and Environmental Protection, Bilthoven, The Netherlands, Report no. 724903003, 46 pp.

De Visser P,H,B., 1991. Manipulation of the water and nutrient supply in two forest ecosystems in the Netherlands that are exposed to acid atmospheric deposition. Dutch Priority Programme on Acidiffcation, Report no. 100.1.

Eldhusct, T., A. Göransson \& T, Ingestad, 1987. Aluminum toxicity in forest tree seedlings. In: T.C. Hutchinson \& K.M. Meema (eds.), Effects of Atmospheric Pollutants on Forests, Wetlands and Agricultural Ecosystems, p. 401-409. Springer-Verlag, Berlin.

Göransson, A. \& T.D. Eldhuset, 1991. Effects of aluminium on growth and nutrient uptake of small Plcea ables and Pinus sylvestris plants. Trees 5: 136-142.

Groffman, P.M. \& J.M.Tiedje, 1989. Denitrification in northern temperate forest soils: spatial and temporal patterns at the landscape and seasonal scales. Soil Biology and Biochemistry 21: 613-620.

Gundersen, P. \& L, Rasmussen, 1990. Nitrification in forest soils: effects from nitrogen deposition on soil acidification and aluminum release. Reviews of Environmental Contamination and Toxicololgy $113 ; 1-45$

Jolinson, D.W, D.W. Cole, H. Van Miegroet \& F.W. Horng, 1986. Factors affecting anion movement and retention in four forest soils. Soil Science Society of America Journal 50: 776-783.

Keltjens, W.G. \& E.yan Loenen, 1989. Effects of aluminium on growth and nutritional composition of hydroponically grown seedlings of five different forest tree species. Plant and Soil 119: 39-50.

Kreutzer, K., A. Göttlein \& P.Pröbstle, 1991. Dynamik und chemische Auswirkungen der Auflōsung von Dolomilkalk unter Fichte (Picea abies [L.] Karst.). In: K.Kreutzer \& A.Gōttlein (eds.), Ōkosystemforschung Höglwald, p. 186-204. Forstwissenschaftiche Forschungen, Heft 39, 1991.

Kricbitzsch, W.U., 1978. Stickstoffnachlieferung in Sauren Waldbőden Nordwestdeutschlands. Scripta Geobotanica 14, Verlag Erich Goltze KG, Göttingen, 66 pp.

Kuyper, Th,W., 1990. Some effects of forest fertilisation on ectomycorrhizal fungi and ectomycorrhizas: implications for tree response and nitrogen pollution. In: H.Persson (ed.), Above and Belowground Interactions in Forest Trees in Acidified Soils, p. 66-73. Air Pollution Research Report 32.

Leek, N.A., 1990. Methods for forest fertilization. (In Dutch with English summary) Meststoffen 1990(3): 7-13.

Marsehner, B., K. Stahr \& M. Renger, 1989. Potential hazards of lime applications in a damaged pine forest ccosystem in Berlin, Germany. Water Air and Soil Pollution 48: 45-57

Marschner, H., M. Hăussling \& E. George, 1991. Ammonium and nitrate uptake rates and rhizosphere pH in non-mycorrhizal roots of Norway spruce [Picea abies (L.) Karst.]. Trees 5: 14-21.

Matzner, E., P.K.Khanna K.J.Meiwes \& B.Ulrich, 1983. Effect of fertilization on the fluxes of chemical elements through different forest ecosystems. Plant and Soil 74: 343-358.

Mengel, K. \& E.A. Kirkby, 1987! Principles of Plant Nutrition. International Potash Institute, Bern, Switzerland, $687 \mathrm{pp}$.

Mulder, J. \& N, van Breemen, 1987. Differences in aluminium mobilization in spodosols in New Hampshire (USA) and in the Netherlands as a result of acid deposition. In: T.C.Hutchinson \& K.Mee$\mathrm{ma}$ (eds.); Effects of Atmospheric Air Pollutants on Forests, Wetlands and Agricultural Ecosystems, p. 361-376, Springer-Verlag, Berlin, Heidelberg.

Nye, P.H. \& P.B. Tinker, 1977. Solute Movement in the Soil-Root System. Blackwell Scientific Publications, Oxford, $342 \mathrm{pp}$.

Reynolds, E.R.C., 1984. A simple method for the extraction of soil solution by high speed centrifuge. Plant and Soil 78: 437-440.

Salırawat, K.L., D.R, Keency \& S.S. Adams, 1985. Rate of aerobic nitrogen transformations in six acid climax forest soils and the effect of phosphorus and $\mathrm{CaCO}_{3}$. Forest Science 31: 680-684.

SAS Institute Inc, 1990. SAS/STAT User's Guide, Version 6, Fourth Edition. SAS Institute Inc., Cary NC,

Skeffington, R.A, 1990. Accelerated nitrogen inputs - A new problem or a new perspective? Plant and Soll 128: 1-11. I.

Tietema, A, 1992. Nitrogen Cyeling and Soil Acidification in Forest Ecosystems in the Netherlands. $\mathrm{PhD}$ thesis, University of Amsterdam, the Netherlands, $140 \mathrm{pp}$.

Tietema, A. \& J.M. Verstraten, 1992. Nitrogen cycling in an acid forest ecosystem in the Netherlands under inereased atmospheric nitrogen input. The nitrogen budget and the effect of nitrogen transfor- 


\section{RESPONSE OF A SCOTS PINE STAND TO FERTILIZATION. 2.}

mations on the proton budget. Biogeochemistry 15: 21-46.

Ulricl, B., 1983. Soil acidity and its relations to acid deposition. In: B.Ulrich \& J.Pankrath (eds.), Effects of Accumulation of Air Pollutants in Forest Ecosystems, p. 127-146. D. Reidel Publ. Comp., Dordrecht, the Netherlands.

Van Breemen, N., J. Mulder \& J.J.M. van Grinsven 1987. Impacts of acid atmospheric deposition on woodland soils in the Netherlands: II. Nitrogen transformations. Soll Science Society of America Journal 51: 1634-1640.

Van Breemen, N. \& E.R.Jordens, 1983. Effects of atmospheric ammonium sulfate on calcareous and non calearcous soils of woodlands in the Netherlands. In: B.Ulrich \& J.Pankrath (eds.), Effects of Accumulation of Air Pollutants in Forest Ecosystems, p. 171-182. D.Reidel Publ. Comp. Dordrecht, the Netherlands.

Van Grinsven, J.J.M., 1988. Computation of above and below ground hydrology. In: N. van Breemen, W,F.J, Visser \& Th. Pape (eds.), Biogeochemistry of an Oak-woodland Ecosystem in the Netherlands Affected by Acid Atmospheric Deposition. Agricultural Research Report 930, p. 72-88. Pudoc, Wageningen, the Netherlands.

Van Grinsven, J.J.M., J.Kros, N.van Breemen, W.H.van Riemsdijk \& E.van Eek 1989. Simulated response of an acid forest soil to acid deposition and mitigation measures. Netherlands Journal of Agricultural Sclence 37: 279-299.

Van Grinsven, J.J.M., L.G.Wesselink, M.Schroeder \& N. van Breemen, 1991. Soil acidification and solute budgets for forested lysimeters in Nordrhein-Westfalen. Zeitschrift für Pflanzenernährung und Bodenkunde 154: 181-188

Vitousek, P.M., J.R. Gosz, C.C. Grier, J.M. Melillo, W.A. Reiners \& R.L. Todd, 1979. Nitrate losses from disturbed ecosystems. Science 204: 469-474.

Wright, R.F., N. van Breemen, B.Emmet, J.G.M.Roelofs, A.Tietema, H.A.Verhoef, M.Hauhs, L,Rasmussen, H.Hultberg, H.Persson \& A.O.Stuanes, 1991. NITREX - Nitrogen saturation experiments, In: A. Teller, P.Mathy \& J.N.R. Jeffers (eds.), Responses of Forest Ecosystems to Environmental Changes, p. 335-341. Elsevier Science Publishers Ltd., Essex, England. 